\title{
LIGHT AND SCANNING ELECTRON MICROSCOPIC DESCRIPTION OF RHADINORHYNCHUS BICIRCUMSPINIS HOOPER 1983 (ACANTHO- CEPHALA) INFECTING THE BAYAD BAGRUS BAJAD (BAGRIDAE). NEW HOST AND LOCALITY RECORDS FROM THE RIVER NILE, QENA, EGYPT BY
}

\author{
KAREEM MORSY ${ }^{1}$, KHALAF N. AMMAR $^{2}$, ABDEL-NASSER A. HUSSEIN², \\ and ALI MANSOUR ${ }^{2}$ \\ Department of Zoology, Faculty of Science, Cairo University and Department \\ of Zoology ${ }^{2}$, Faculty of Science, South Valley University, Egypt \\ ( ${ }^{\circ}$ Correspondence: Kareemsaid156@yahoo.com)
}

\begin{abstract}
Rhadinorhynchus bicircumspinis, an acanthocephalan parasite recovered from the intestine of Bagrus bajad (Bagridae) captured from water locations along the River Nile at Qena governorate. Ten/seventy $(14.28 \%)$ were infected. Morphologically and morphometrically by light and scanning electron microscopy, parasite was creamy white, slightly curved without annulations. Body was 7-10 (8 \pm 2$) \mathrm{mm}$ long x 0.52$0.71(0.62 \pm 0.02) \mathrm{mm}$ wide in male \& $7-15(12 \pm 2) \mathrm{mm}$ long and $0.43-0.68(0.55 \pm 0.02) \mathrm{mm}$ wide in female. Proboscis, long, with short neck measured 1.42-1.83 (1.66 \pm 0.02$) \mathrm{mm}$ in males \&1.54-1.96 $(1.75 \pm 0.03) \mathrm{mm}$ in females, covered with $12-15$ rows of $20-23$ hooks each. Proboscis receptacle elongated and double walled lemnisci were two, tubular, elongated on proboscis receptacle sides. Trunk was long, spinose anteriorly. Two postequatorial contiguous testes were observed in male worms with four very long tubular cement glands overlapped at the posterior margin of posterior testis. In female worms, ovarian balls, uterus and a short vagina were observed at the posterior end of the body cavity. Immature, fusiform eggs with polar prolongations were recorded in the body cavity. No mature eggs seen. Genital pore was subterminal. The present parasite was compared with similar species from different hosts, $R$. selkirki, $R$. trachuri, $R$. cololabis and $R$. pristis, which showed that the isolated parasite was $R$. bicircumspinis as a new host and locality; the River Nile at Qena Governorate in Egypt
\end{abstract}

Key words: Rhadinorhynchus bicircumspinis, Acanthocephala, Bagrus bajad, River Nile, Qena, Egypt.

\section{Introduction}

Fish is one of the most important sources among the food products of animal origin because of their content of high quality biological animal protein, lipids, vitamins, essential fatty acids and several kinds of minerals (El-Garhy et al, 2017; Kuras et al, 2017; Morsy et al, 2016). To obtain healthy and quality meat fish, it is necessary that the fish should be free from all types of infections like viral, bacterial and parasitic. Fish parasites act as a stress factor, producing a decrease in the body weight, lowering the immunity and rendering growth, which make fish more susceptible to other diseases.

The bayad (Bagrus bajad Forsskål, 1775), is a species of bagrid catfish from Africa (Holden, 1972). This species spends nearly the whole of the daylight hours in crevices of rocks and is therefore seldom seen. It lives and feeds on or near the bottom. Adults are exclusively piscivorous; it preys on small fish. This species is well distributed in the River Nile at Qena Governorate in the southern part of Egypt where the environment mainly the water temperature is adequate. Their economic importance is due to their well marketable size, good taste flesh and acceptability by the Egyptian people (Boulenger, 1907; Bishai and Khali, 1997). Acanthocephalans are helminth parasites that use arthropods and vertebrates as the intermediate host to complete their life cycles. These helminthes lack alimentary tract and are characterized by the presence of a proboscis armed with hooks, a syncytial epidermis and a lacunas system with circulatory channels that promote direct absorption of nutrients through the body wall (Mattiucci et al, 2014; Smales, 2014). Acanthocephalans are frequently seen in the intestines of freshwater, marine fish and other vertebrates (Li et al, 2017). Rhadinorhynchidae Travassos, 1923 is a family of parasitic worms from the order Echinorhynchida with the Rhadinorhynchus Lühe, 1911 species identi- 
fied from 36 host individuals (Barton and Smales, 2015; Zarei et al, 2016). They are parasitic as adults in the intestine of fish. Anterior body region armed with scattered cuticular spines, ensheathed by cuticular folds. Proboscis and proboscis receptacle very long, ventral proboscis hooks stronger than dorsal. Proboscis receptcle with a double walled; muscular sac with brain located near its middle. Lemnisci long, fingerlike.

The present study aimed to determine the prevalence of natural infection as well as morphological description of acanthocephalan parasites isolated from the common bayad Bagrus bajad (Bagridae) caught from Al-Ashraf Al-Qibliyyah, along the River Nile at Qena Governorate, Egypt

\section{Materials and Methods}

Samples of 70 Bagrus bajad (Bagridae) fish caught from water location at Al-Ashraf AlQibliyyah along the River Nile at Qena Governorate, Egypt. Fish samples were transported immediately to the research laboratory, at Department of Zoology, Faculty of Science, South Valley University. They were identified according to Randall et al. (1992). Examination of all internal organs for the prevalence of endoparasitic infection was conducted. The digestive tract contents were poured into physiological saline solution $(0.9 \%)$ and examined by dissecting microscope. Live acanthocephalan worms were detected and kept in tap water for a few hours until proboscides were everted then fixed in $10 \%$ neutral buffered formalin for $48 \mathrm{hr}$, placed overnight in distilled water, stained overnight in acetocarmine, dehydrated in ethanol series, cleared in clove oil, and permanently mounted on glass slides using Canada balsam. Photomicrographs were taken using Carl Zeiss 19386 photomicroscope equipped by a power shot Canon digital Camera (A 630). Measurements were taken as a mean $\pm \mathrm{SD}$ (range) according to the guidelines of Lom and Arthur (1989). To reveal the surface structures of the parasite, the specimens were fixed in $3 \%$ buffered glutaraldehyde, washed in cacodylate buffer, and dehydrated in a graded series of ethanol alcohol $(10 \%, 20 \%, 30 \%, 40 \%, 50 \%, 60 \%$,
$70 \%, 80 \%, 90 \%$ and $100 \%)$. After passing through an ascending series of Genosolv-D, they were processed in a critical point drier "Bomer - 900" with freon 13, and sputter coated with gold - palladium in a Technics Hummer V (Lee, 1993), and examined with an EtecAutoscan at $20 \mathrm{KV}$ Jeol scanning EM.

\section{Results}

Ten $(14.28 \%)$ of seventy worms (six adult males and 4 gravid females) were collected from the intestine of B. bajad. The following description is based on all of the recovered 10 specimens.

Description: Worms were creamy white in color, slightly curved without annulations.

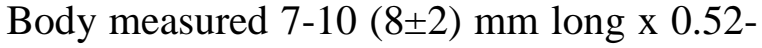
$0.71(0.62 \pm 0.02) \mathrm{mm}$ wide in males and 7 $15(12 \pm 2) \mathrm{mm}$ long x 0.43-0.68 (0.55 \pm 0.02$)$ $\mathrm{mm}$ wide in females. Proboscis was long, cylindrical, with short neck measured 1.42$1.83(1.66 \pm 0.02) \mathrm{mm}$ in males and 1.54$1.96(1.75 \pm 0.03) \mathrm{mm}$ in females. It was covered with 12-15 rows of 20-23 hooks each. Hooks of anterior rows were larger than the remaining rows, strongly curved basally, measured $0.06-0.09(0.07 \pm 0.02) \mathrm{mm}$ long from the curved height to tip of the straight, backwardly pointing blade. Proboscis receptacle elongated and double walled measured 1.79-2.98 (2.11 \pm 0.02$) \mathrm{mm}$ long. Lemnisci were two, tubular, elongated on sides of proboscis recep-tacle measured 1.64-2.27 $(1.78 \pm 0.02) \mathrm{mm}$ long, Trunk long and slender, spinose anterio-rly irregular complete circles of spines.

Male: Reproductive system situated in posterior half of trunk; testes usually postequatorial, elongate, almost equal in size, and contiguous; anterior testis 0.47-0.84 $(0.73 \pm 0.02) \mathrm{mm}$ long $\mathrm{x}$ 0.25-0.32 $(0.29 \pm 0.02) \mathrm{mm}$ wide, posterior one 0.52 $\begin{array}{llll}0.99 & (0.50 \pm 0.02) & \text { long } x & 0.17-0.33\end{array}$ $(0.31 \pm 0.02)$ wide. Four very long tubular multinucleated cement glands usually overlapped at posterior margin of posterior testis measured 2.51-3.22 (3.10 \pm 0.02$) \mathrm{mm}$ long, which products were collected in a cement reservoir posteriorly. Spermatozoa carried by common sperm duct and collected in 
a seminal vesicle gonopore terminal, bursa capped with copulatory plug.

Female: Reproductive system simple consisted of ovarian balls at body cavity posterior end, uterus and a short vagina. Immature eggs in body cavity, fusiform with polar prolongations of middle membrane, immature eggs seen. Genital pore was sub terminal.

\section{Taxonomic summary}

Type species: Rhadinorhynchus bicircumspinis Hooper (1983)

Family: Rhadinorhynchidae Travassos (1923)

Type Host: Common Bayad (Bagrus bajad) (F: Bagridae Forsskål, 1775).

Site of infection: intestine

Type locality: River Nile at Qena Governorate (Locality of Al- Ashraf AlQibliyyah), Egypt.

Prevalence: 10/70 fish (14.28\%) naturally infected, infection increased in winter $6 / 20$ $(30 \%)$ and decreased in summer 4/50 (8\%).

Etymology: Specific name refers to two rows of spines surrounding proboscis receptacle posterior.

\section{Discussion}

About 35 species of Rhadinorhynchus were described from 36 host individuals (Smales, 2014). The characteristic features to distinguish between species of genus were reviewed (Chandler, 1934; Petrochenko, 1956; Tripathi, 1956; Cable and Linderoth 1963; Yamaguti, 1963; Golvan, 1969) and Smales (2014). Proboscis armature, trunk spination, morphology and morphometrics of the present male and female specimens in were consistent with $R$. bicircumspinis after the keys of Rhadinorhynchus species (Amin et al, 2011; Amin, 2013). This species was originally described from the lumen of lower intestine of the host fish Platycephalus bassensis in Northwest Solitary Island region (Hooper, 1983) based only on a single male specimen. Thus, the present species shared commonest characteristic features distinguishing this species from others such as: Proboscis armed with 12-15 longitudinal rows of 20-23 hooks each row, larger row of hooks present protruding at right angles to proboscis base, presence of unequal-sized cement glands posterior to testes and testes are contiguous. But, the two rows of minute spines described by Hooper (1983) on the proboscis receptacle posterior edge were not observed herein. Spines were detected in the present specimens, as might be present or absent from the proboscis receptacle posterior edge. This did not seem to be a good reason for a new species. Comparative measurements between other species collected from different host species worldwide were given. R. selkirki Van Cleave (1921), $R$. trachuri Harada (1935) and $R$. cololabis Laurs and McCauley (1964) resemble the present species in having 12 rows of proboscis hooks, with approximately 23 hooks each row. Male $R$. selkirki differs in the longer trunk, proboscis sheath, and in distribution of body spines. $R$. trachuri also differs from $R$. bicircumspinis in having a shorter trunk and proboscis sheath. $R$. cololabis has a shorter proboscis and proboscis sheath, and has fewer spines on the posterior field of trunk spines. $R$. pristis has 14-16 rows of proboscis hooks with 26 hooks per row (Yamaguti, 1963). So, R. bicircumspinis Hooper, 1983 is the valid taxonomic species of acanthocephalan recovered from B. bajad in the River Nile at Qena Governorate, isolated for the first time from this host fish, so this represents new host and locality records.

\section{Conclusion}

Rhadinorhyncus bicircumspinis Hooper (1983) was recorded from Bagrus bajad (new host), at Qena, (new locality) during a general survey on parasites infecting fresh water fishes captured from the River Nile at Qena Governorate, Egypt. The parasite was described morphologically and morphometrically by light and SEM. One must focus for other parasitic fauna infecting fishes.

\section{Acknowledgment}

Authors would like to thank the staff members Departments of Zoology, Faculties of Science, Cairo University, and South Valley University, Egypt

\section{References}

Amin, OM, 2013: Classification of the Acanthocephala. Folia Parasitol. 60:273-305. 
Amin, OM, Heckman, RA, Van Ha, N, 2011: Description of two new species of Rhadinorhynchus (Acanthocephala, Rhadinorhynchidae) from marine fish in Halong Bay, Vietnam, with a key to the species. Acta Parasitol. 56: 67-77.

Barton DP, Smales LR, 2015: Acanthocephalan Cystacanths from Flatfish (Order Pleuronectiformes) in Tropical Australian Waters. J. Parasitol. 101, 4:429-35.

Bishai, HM, Khalil, MT, 1997: Freshwater fishes of Egypt: Egyptian Environmental Affairs Agency.

Boulenger, GA, Loat, L, 1907: Zoology of Egypt: The fishes of the Nile: Published for the Egyptian Government by Hugh Rees, Ltd, London.

Cable, RM, Linderoth, J, 1963: Taxonomy of some Acanthocephala from marine fishes with re-ference to species from Curacao, N.A. and Jamaica, W.1. J. Parasitol. 49: 706-716.

Chandler, AC, 1934: A revision of the genus Rhadinorhynchus (Acanthocephala) with descriptions of genera and species. Parasitol. 26: 352-8.

El-Garhy M, Cali A, Morsy K, Bashtar AR, Al Quraishy, S, 2017: Ultrastructural characterization of Pleistophora macrozoarcidis Nigerelli 1946 (Microsporidia) infecting the ocean pout Macrozoarces americanus (Perciformes, Zoarcidae) from the gulf of Maine, MA, USA. Parasitol. Res. 116, 1:61-71.

Golvan, YJ, 1969: Systematique des acanthocephales (Acanthocephala Rudolphi, 1801) l'Ordre des Palaeacanthocephala Meyer (1931) la Superfamille des Echinorhynchioidea (Cobbold, 1876) Golvan et Houin (1963). Memoires du Museum National D'Histoire Naturelle. 57:1-373.

Harada, I, 1935: Zur Acanthocephalen fauna von Japan: Memoirs of the Faculty of Science \& Agri-culture, Taikoku Imperial University. 14:423.

Holden, M, Reed, W, 1972: West African Freshwater fishes, Longman, UK.

Hooper, JNA, 1983: Parasites of esturine and oceanic flathead Fishes from Northern New South Wales. Aust. J. Zool. 90:S1-69.

Kuras R, Janasik B, Stanislawska M, Kozlows ka L, Wasowicz W, 2017: Assessment of mercury intake from fish meals based on intervention research in the Polish Subpopulation. Biol. Trace Elem Res.:27 (Epub ahead of print).
Laurs, RM, McCauley, JE, 1964: A new acanthocephalan from the Pacific saury. J. Parasitol. 50:69-71.

Li, L, Yang, Y, Zhang, LP, 2017: Morphological and molecular study of Longicollum pagrosomi Yamaguti, 1935 (Acanthocephala: Pomphorhynchidae) from the barred knifejaw Oplegnathus fasciatus (Temminck \&amp; Schlegel) (Perciformes: Oplegnathidae) in the East China Sea. Syst. Parasitol. 94, 2:255-61.

Mattiucci, S, Garcia, A, Cipriani, P, Santos, MN, Nascetti, G, et al, 2014: Metazoan parasite infection in the swordfish, Xiphias gladius, from the Mediterranean Sea and comparison with Atlantic populations: implications for its stock characterization. Parasite 21:35.

Morsy K, Semmler M, Al-Olayan E, Mehlhorn H, 2016: Henneguya collaris sp. nov., (Myxosporidia), parasite of the Greenband Parrotfish Scarus collana Rüppell, 1835 (Actinopterygii, Scaridae) from the Red Sea, Egypt: A light and electron microscopic study. Parasitol. Res. 115, 6:2253-61.

Petrochenko, VI, 1956: Acanthocephala of domestic and wild animals. Vol.1. Moscow, Izdatel'stvo Akademii Nauk SSSR (English translation by Israel Program for Scientific Translations, 1971).

Randall, DA, Shao Q, Moeng, CH, 1992: A second order bulk boundary-layer model. J Atmos Sci. 49:1903-23.

Smales, LR, 2014: The genus Rhadinorhynchus (Acanthocephala: Rhadinorhynchidae) from marine fish in Australia with the description of four new species. Acta Parasitol. 59, 4:721-36

Tripathi, YR, 1956: Studies on parasites of Indian fishes V. Acanthocephalans. Rec. Ind. Mus. 54:61-99.

Van Cleave, HJ, 1921: Acanthoccphala collected by the Swedish Expedition to the JuanFernandez Island (1916-1917). In: Natural History of the Juan-Fernandez and Easter Islands.

Yamaguti, S, 1963: Systema Helminthum, Acanthocephala. Wiley Interscience: New York, NY. 5:1-423.

Zarei, Z, Mohebali, M, Heidari, Z, Davoodi, J, Shabestari, A, et al, 2016: Helminth Infections of Meriones persicus (Persian Jird), Mus musculus (House mice) and Cricetulus migratorus (Grey Hamster): A Cross-Sectional Study in Meshkin-Shahr District, Northwest Iran. Iran J. Parasitol. 11, 2:213-22. 
Table 1 Comparison between some important parameters of morphologically similar species of Rhadinorhynchus recorded and of current study (measurements in $\mu \mathrm{m}$, otherwise stated).

\begin{tabular}{|c|c|c|c|c|c|c|}
\hline Aspects & $\begin{array}{l}\text { R. selkirki } \\
\text { Van Cleave (1921) }\end{array}$ & $\begin{array}{l}\text { R. trachuri } \\
\text { Harada (1935) }\end{array}$ & $\begin{array}{l}\text { R. pristis Cable and } \\
\text { Linderoth (1963) }\end{array}$ & $\begin{array}{l}\text { R. cololabis Laurs } \\
\text { and McCauley (1964) }\end{array}$ & $\begin{array}{l}\text { R. bicircumsp-inis } \\
\text { Hooper (1983) }\end{array}$ & $\begin{array}{l}\text { R. bicircumspinis } \\
\text { (Present study) }\end{array}$ \\
\hline Host & Caranx georgianus & $\begin{array}{l}\text { Trachurus japoni- } \\
\text { cus }\end{array}$ & Coryphaena hippurus & Cololabis saira & $\begin{array}{l}\text { Plattycephalus } \\
\text { bassensis }\end{array}$ & Bagrus bajad \\
\hline Locality & $\begin{array}{l}\text { Juan Fernandez } \\
\text { Islands, West Pacific }\end{array}$ & Tokyo, Japan & Curacao, Antilles & Oregon, U.S.A. & $\begin{array}{l}\text { Coffs Harbour, } \\
\text { Australia }\end{array}$ & Qena, Egypt \\
\hline $\begin{array}{l}\text { Body } \\
\text { length } \mathrm{x} \text { width }\end{array}$ & - & - & - & - & - & $\begin{array}{l}\text { Male: } 7-10 \times 0.52-0.71 \mathrm{~mm}, \text { Female: } \\
7-15 \times 0.43-0.68 \mathrm{~mm}\end{array}$ \\
\hline Proboscis length & 2000 & 1700 & $1560-2170$ & $1600-1900$ & 3200 & $\begin{array}{l}\text { Male: } 1.42-1.83 \mathrm{~mm} \text {, Female: } 1.54- \\
1.96 \mathrm{~mm}\end{array}$ \\
\hline Hooks per row & 24 & $22-24$ & 36 & $20-21$ & 23 & $20-23$ \\
\hline Rows of hooks & $12-14$ & 12 & 24 & 10 & 12 & $12-15$ \\
\hline $\begin{array}{l}\text { Proboscis sheath } \\
\text { Length }\end{array}$ & $2500-3800$ & 1600 & $3000-4000$ & $2400-3140$ & 3520 & $1.79-2.98 \mathrm{~mm}$ \\
\hline Internal spines & Absent & Absent & Absent & Absent & Present & Absent \\
\hline Lcmnisci length & (--------- & Larger & Shorter & Larger & Larger & $1.64-2.27 \mathrm{~mm}$ \\
\hline Testes diameter & -------- & $700-400 \times ?$ & $530-680 \times 240$ & $800-2200 \times 350-700$ & $\begin{array}{l}1305-1472 \text { x 424- } \\
491\end{array}$ & $\begin{array}{l}\text { Anterior: } 0.47-0.84 \times 0.25-0.32 \& \\
\text { Pos-terior: } 0.52-0.99 \times 0.17-0.33 \mathrm{~mm}\end{array}$ \\
\hline Cement glands & -------- & 4 & 4 & 4 & 4 & 4 \\
\hline
\end{tabular}

Figs.1-9: Rhadinorhynchus bicircumspinis. 1- Whole mount preparation of female worm with proboscis $(\mathrm{P})$, trunk $(\mathrm{T})$, proboscis receptacle (PR), two lemnisci (L). 2 Male, 2 testes (TE), cement glands (CG), cement receptacle (CR) and seminal vesicle (SV), S abbreviated for trunk spines. 3-9 High magnifications of: 3, 4 Posterior end of female, ovarian balls (OB), uterus (UT) and vagina (V); 5 Immature eggs (EG); 6 Proboscis (P) and ihooks $(\mathrm{H}) ; 7$ Proboscis hooks $(\mathrm{H}) ; 8$ Trunk spines (SP); 9 Posterior end of male, seminal vesicle (SV); bursa (B).

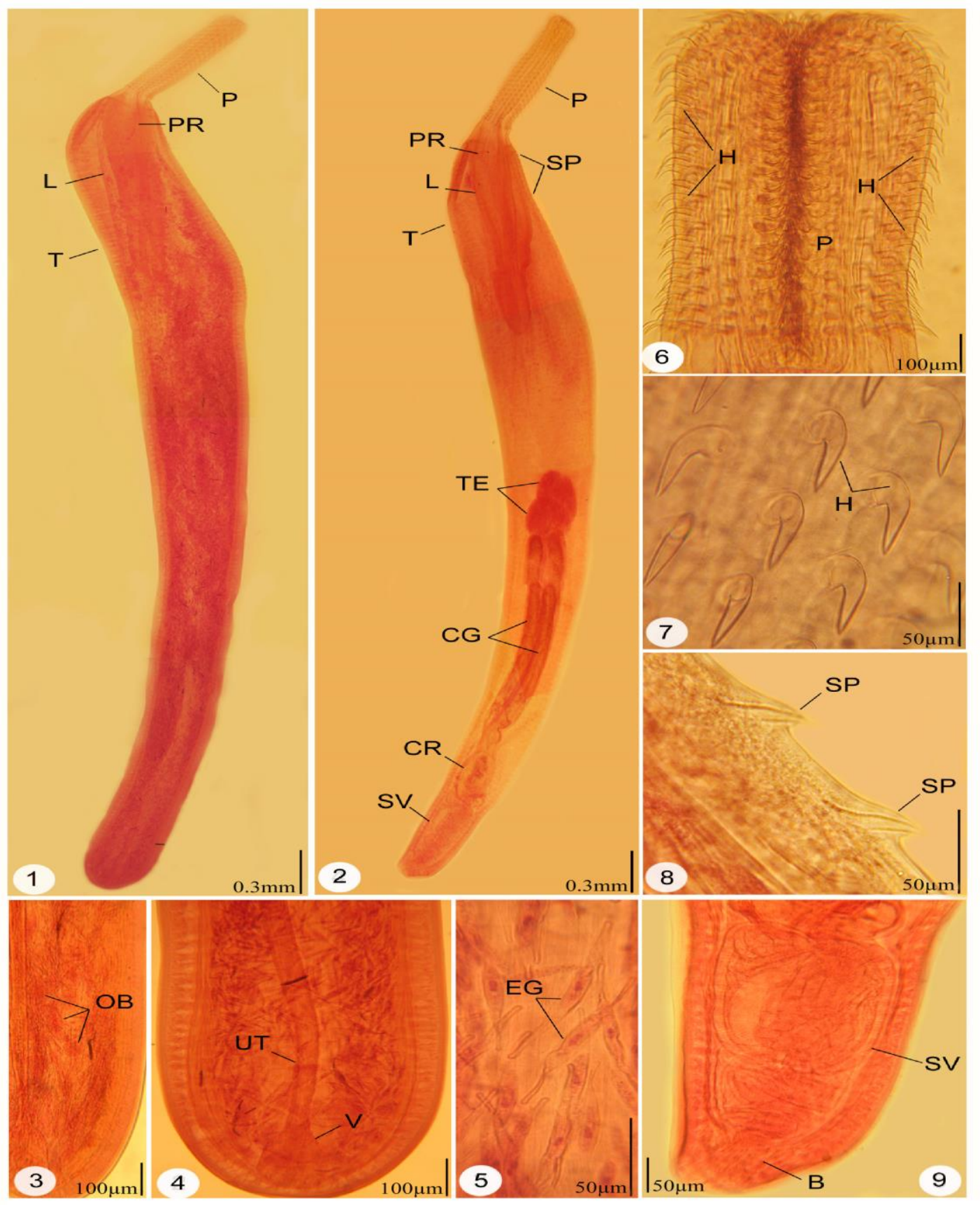


Figs.10-13: SEM showing: 10 Apical view of worm proboscis (P) equipped with hooks (H). 11 \& 12 Magnified hooks (H). 13 Spines (SP) of worm trunk (T).
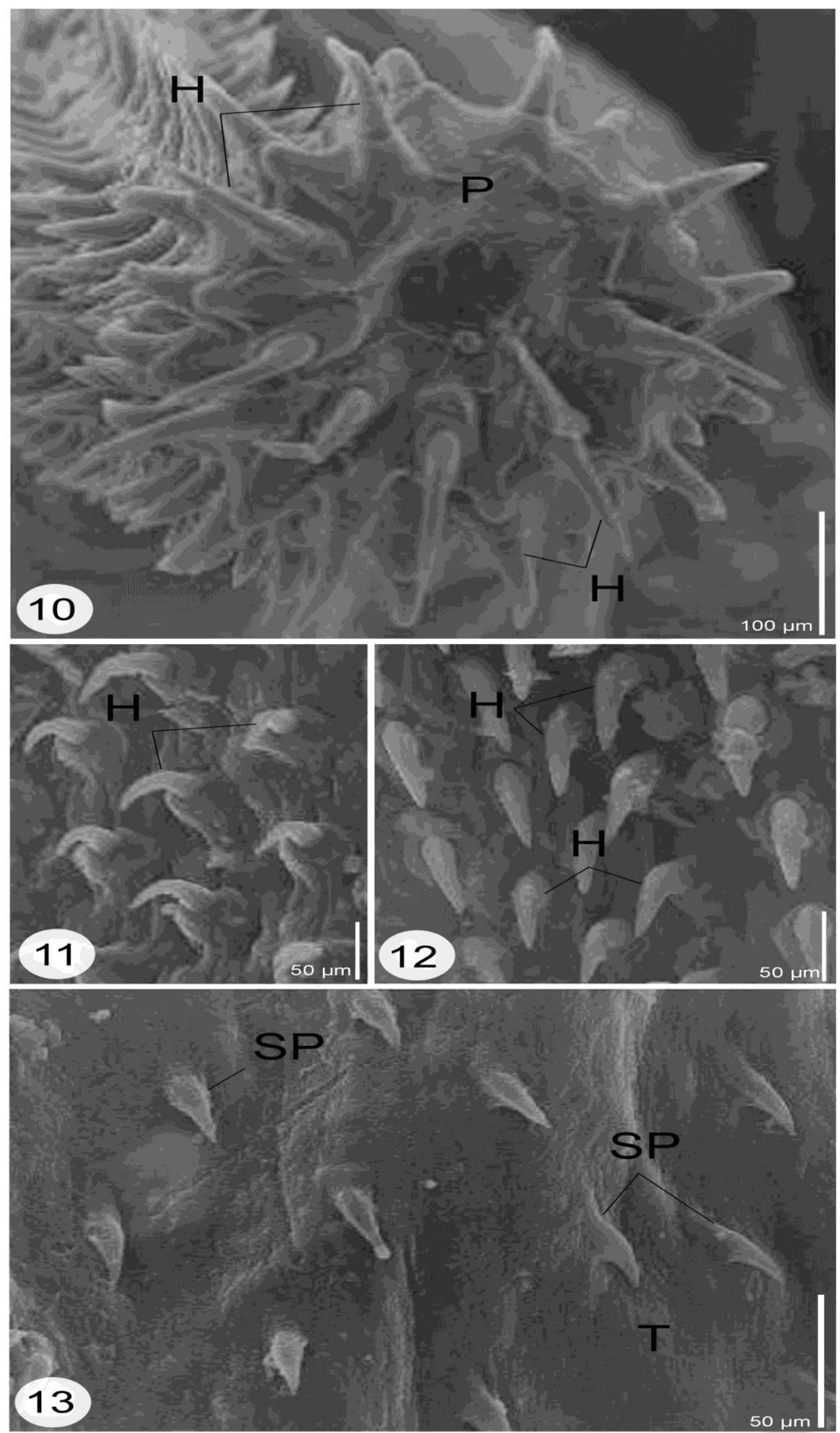